\title{
Quantitative, qualitative, and collaborative methods: approaching indigenous ecological knowledge heterogeneity
}

\author{
Jeremy Spoon ${ }^{1}$
}

\begin{abstract}
I discuss the use of quantitative, qualitative, and collaborative methods to document and operationalize Indigenous ecological knowledge, using case studies from the Nepalese Himalaya and Great Basin. Both case studies applied results to natural and cultural resource management and interpretation for the public. These approaches attempt to reposition the interview subjects to serve as active contributors to the research and its outcomes. I argue that the study of any body of Indigenous knowledge requires a contextspecific methodology and mutually agreed upon processes and outcomes. In the Nepalese Himalaya, I utilized linked quantitative and qualitative methods to understand how tourism influenced Sherpa place-based spiritual concepts, species, and landscape knowledge inside Sagarmatha (Mount Everest) National Park and Buffer Zone. In this method, Sherpa collaborated in the development of the research questions, the design, and in the review of results. The research in the Great Basin employed collaborative qualitative methods to document Numic (Southern Paiute and Western Shoshone) ecological knowledge of federal lands within their ancestral territory and attempted to piece together fragmented and contested histories of place. In this method, Numic peoples collaborated on the development of research questions and design; however they also conducted most of the interviews. In both cases, I selected particular suites of methods depending on the context and created forums for the translation of this information to applied outcomes. The methods were also improved and innovated through praxis.
\end{abstract}

Key Words: collaborative methods; Great Basin; Himalayas; Indigenous ecological knowledge; linked quantitative and qualitative methods; Numic peoples (Southern Paiute and Western Shoshone); Sherpa

\section{INTRODUCTION}

Over time, climatic fluctuations, forced relocations, economic recessions, and so on are factors that can shift the relationships between Indigenous peoples and the environment. Indigenous peoples are considered first peoples to a particular geographic location who have a voluntary, collective cultural identity. They self-identify as Indigenous peoples and are recognized by outsiders as such. Most Indigenous peoples have also experienced some form of subjugation, marginalization, disposition, exclusion, or discrimination in the past and/or present (see Asch et al. 2004, Spoon and Arnold 2012). Ecological knowledge and practices consequently adapt to deal with this changing relationship between Indigenous peoples and their environment. Social science methods, particularly from anthropology, are uniquely positioned to understand the dynamic character of this knowledge and these practices, which are situated and assembled in particular times and places.

I discuss the use of linked quantitative, qualitative, and collaborative methods to document and operationalize Indigenous ecological knowledge, using case studies from the Nepalese Himalaya and Great Basin. Both studies also illustrate how to apply research to resource management, e.g., pine nut harvests as a form of habitat management, and the interpretation of interconnected natural and cultural resources to the public, e.g., films, visitor centers, interpretive trails, public art, campgrounds, picnic areas, and live programs. In both cases, the methodological tool-kit was selected through preliminary research, which included consultation with the host community and appropriate reconnaissance.

As a starting point for creating relevant, thorough research designs, I propose a framework for critically addressing the concept of Indigenous ecological knowledge as a moving target. I follow with the two case studies, through which I attempted to generate useful and balanced information about the relationships between Indigenous peoples and the environment. I then compare and contrast the approaches and discuss the implications of these methods to future research.

\section{DEFINING INDIGENOUS ECOLOGICAL KNOWLEDGE}

Defining what Indigenous ecological knowledge is and how it functions is integral to constructing germane, rigorous research designs. To generalize, Indigenous ecological knowledge is a cumulative system of adaptive knowledge and practices about the relationships of living beings with one another and with their environment. I group knowledge and practices together for the sake of clarity and to create a broad research universe, which can be narrowed down through preliminary research and reconnaissance with meaningful local consultation. Depending on context, research objectives, funder obligations, etc., cognitive information and situated practices may need to be delineated more clearly in a research design. This knowledge is transmitted from generation to generation in various ways and evolves over time through incremental learning and responses to crises and mistakes. It can include creation stories, placebased spiritual values, e.g., sacred trees and water sources, and knowledge of specific resources, e.g., medicinal plants and the location of springs. This knowledge is often coded in language, stories, songs, and more (Berkes and Turner 2006, Turner and Berkes 2006, Berkes 2008). For example, Nuwuvi songs describe geologic events, such as volcanic eruptions, which occurred thousands of years ago.

In this era of global connection, Indigenous ecological knowledge also includes new knowledge, creating hybridized assemblages of knowledges with local and global roots. It includes both explicit, e.g., creation stories, explanations of 
ecological phenomena, and plant harvest knowledge, and tacit dimensions, e.g., performative practices in response to an environmental hazard (Sillitoe 1998, Dove et al. 2009, Lauer 2012). Indeed, Indigenous peoples work for the state, attend and teach at schools, own and operate businesses and large-scale farms, enforce Western conservation strategies, serve in the military, conduct ethnography, and more. Beyond the influence of the physical environment and internal power dynamics within and between Indigenous peoples over time, there are a variety of contexts in which Indigenous peoples have been marginalized by outside hegemonic forces, causing dramatic changes in population dynamics, knowledge transmission processes, and access to natural and cultural resources. For example, colonialism in the United States radically reduced Indigenous populations, severed peoples from their ancestral lands, relocated individuals to reservations, and forced children into boarding schools, which barred the Native people from speaking Indigenous languages and from practicing their spiritual traditions (Spoon and Arnold 2012).

Research designs must therefore take into account ecological knowledge and practices' dynamic (not static) nature. At any specific time, there is variation in who knows/practices what, why, and how. The suite of methods selected should take into account not only a domain of knowledge/practice, e.g., plant knowledge and associated management practices, but also who holds it, i.e., specialization, and what influences its change over time, i.e., ecological, political, and economic factors. Indeed, as soon as information is collected, it is part of the past and is always incomplete. What was once known and practiced, and may have had a beneficial environmental outcome, may have become outmoded or been remade at a later point. Operationalizing certain knowledge to action can have profound social and environmental benefits. Alternatively, restoring obsolete traditions may have less utility.

I now present two case studies in which Indigenous ecological knowledge was documented and applied to various social and environmental issues. The projects were conducted sequentially. I employed a suite of quantitative, qualitative, and/or collaborative methods for each case depending on context and praxis (experience of the researcher).

\section{SHERPA ECOLOGICAL KNOWLEDGE}

This case illustrates a configuration of linked quantitative, qualitative, and collaborative methods to understand the heterogeneity of Sherpa ecological knowledge inside Sagarmatha (Mount Everest) National Park and Buffer Zone, Nepal (Fig. 1). To generalize, the Sherpa migrated from eastern Tibet to the mountainous SoluKhumbu area of Nepal around the midsixteenth century because of war, famine, or drought (Ortner 1989). They are Nyingma Buddhists who have dual, overlapping conceptions of sacred landscape, 'yu-lha' or the mountain home of a protector deity and 'beyul' or a hidden valley set aside by a Buddhist saint for the Sherpa to be populated in a time of need, e.g., war, famine, or drought. Sherpa consider numerous landscape features, e.g., plants, animals, rocks, mountains, and rivers, to be alive and connected to humans. Certain traditions are practiced in the home, whereas others are enacted communally in the monastery and near significant locations, such as forests and water sources. Sherpa maintain land titles within the national park buffer zone and participate in the growing tourism market economy as lodge owners, trekking guides, and more. The national park is currently governed by the state, but does contain some opportunities for Sherpa management recommendations through the local Buffer Zone Management Committees (Spoon 2011a, 2013).

Fig. 1. Sargamatha (Mount Everest) National Park and Buffer Zone, Nepal (locally known as Khumbu and Pharak). Tourist route is in the Imja Khola Valley.

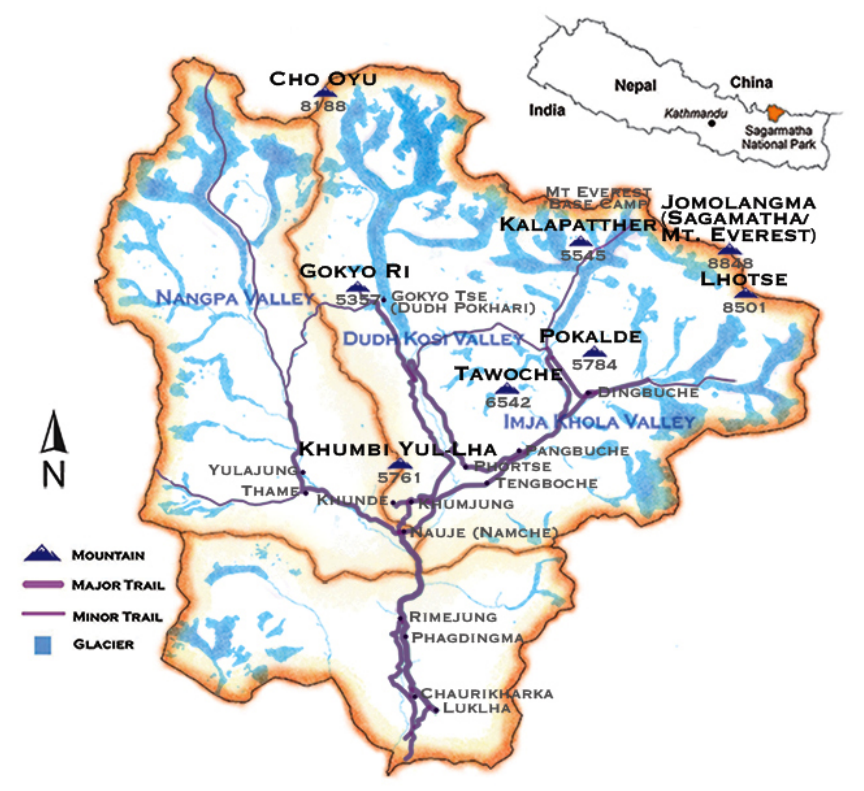

I first decided to go to Nepal because of a connection that I had with the nongovernmental organization (NGO) The Mountain Institute, particularly with Dr. Lhakpa Norbu Sherpa, which I thought would help me to inductively create more locally relevant research that could be applied in some pragmatic way. I conducted four months of exploratory research in 2004 and 2005, which included multiple informal interviews and focus groups with key consultants as well as observation of the tourism industry, herding, farming, etc. The two most common themes, which emerged from these efforts, were that there was a perception of ecological and other knowledge changes occurring between elders and youth, and that this change was more pronounced for those who were participating in tourism businesses. These themes then became the primary hypotheses for subsequent deductive research.

A linked quantitative and qualitative methodology was then conceived in collaboration with key Sherpa and other consultants who assisted in the development of the research questions. Select trained Sherpa research assistants conducted a portion of the demographic questionnaires and local focus groups were enacted to interpret results (Fig. 2). Research was also returned to the host community through a series of presentations, which included a summary of the research results in the Nepali language and discussions about their local meaning (Fig. 3). 
Fig. 2. Focus group conducted by the researcher with Khumbu Bijuli Company staff to present preliminary results related to knowledge of select taxa. December 2006. Photo: Pemba Tshering Sherpa.

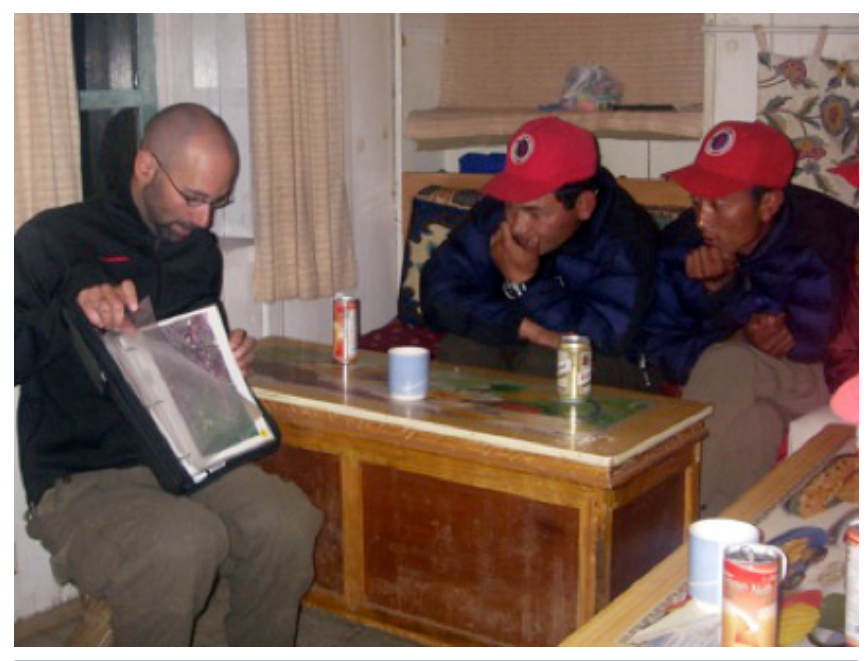

Fig. 3. Research return presentation attendess in Khumjung/ Khunde settlements within Sagarmatha (Mount Everest) National Park and Buffer Zone. Most pictured were part of a stratified random sample of 100 hourseholds that participated in the research. July 2008. Photo: Passang Sherpa.

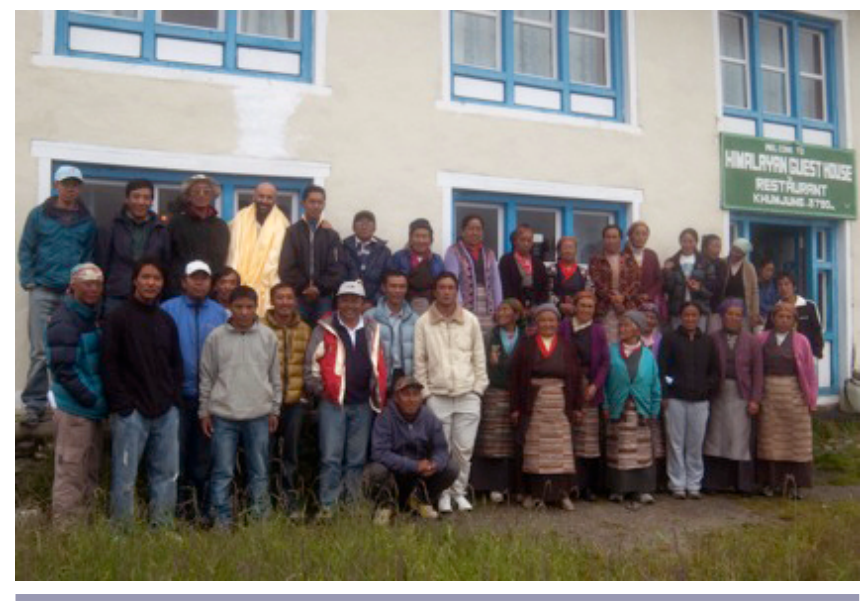

Between 2006 and 2007, the deductive approach was enacted with 100 households from a stratified random sample assembled through electricity records and a local census. Multiple Sherpa assistants were trained to conduct demographic surveys, which I mentored. Together, we utilized structured questionnaires on species and landscape knowledge and semistructured interviews on spiritual concepts with 100 available individuals from the household sample, i.e., 1 from each household. We also conducted semistructured life histories with 24 individuals across select age groups from those who participated in the structured techniques (Spoon 2011 $a, b$ ). Finally, we utilized survey research, carried out by Sherpa research assistants and myself, to frame the economic context, e.g., surveys on the economics and dynamics of tourist visitation and locally owned lodges and tea shops. Our ethnographic methods are suites of participant observation and interview techniques, e.g., unstructured, semistructured, and structured, implemented by the researcher, who had gained a level of rapport through engagement over time with the host community, e.g., 4 months exploratory research, 15 months of continuous fieldwork, or conducted by the host community themselves, e.g., focus groups enacted by representatives of Indigenous communities. They are quantitative, e.g., structured questionnaires on species knowledge, and qualitative, e.g., semistructured life histories. Sample sizes were smaller (e.g., $\mathrm{N}=100, \mathrm{~N}=24$ ), which allowed for follow-up interviews and observation of situated practices. Survey techniques were in the form of structured questionnaires with larger probabilistic sample sizes. Their utility was in providing context, e.g., trend-related household demographics, settlement patterns, and local economic capacity, for the ethnographic data. Their straightforwardness also made them useful in creating opportunities for local research assistants to obtain training and to feel ownership over a portion of the data collection.

The results showed that indeed knowledge change was occurring, especially among the younger generations and the more market integrated households, i.e., households along the tourist route to Mount Everest Base Camp. Quantitative data showed these broader trends according to particular demographics, such as, age, gender, and proximity to the tourist route, and allowed the results to be generalizable to the entire population. Qualitative life histories added depth to these results, helping to show what was motivating the knowledge holders to gain new knowledge, for example, tourism, striving for modernity. It also showed the character of this new knowledge, such as deities gaining new powers to deal with the contemporary context. For example, the goddess who resides on Mount Everest gained the power to provide abundant tourists, as opposed to the past when she afforded the natural resources for successful harvests and grazing (Spoon 2011a, b, 2013).

The research was applied to a Ford Foundation-sponsored project, led by Dr. Lhakpa, which focused on the livelihoods of Sherpa along 'beyul,' i.e., hidden valley, trails. The project produced an ethnographic film and designed exhibits for the park visitor center, which reinforce the Sherpa relationship with place. It also included Sherpa language curriculum development in schools and monasteries and some local livelihood generation activities, such as cultural tourism and visitor home-stays. These products utilized consultants and some results from the research. These outcomes were developed in part with the host community, the national park, and locally engaged NGOs.

Challenges encountered in this project included a sampling bias toward the monastic community in the preliminary research phases. This created a focus on the spiritual concepts, which select monks and elders considered important, rather than on what the lay population actually knew and followed. Expectedly, the complicated nature of the data analysis techniques, e.g., multiple regression, conducted on quantified domains of ecological knowledge isolated some Sherpa individuals from the research results; however, care was taken to communicate these findings in locally relevant terms through multiple presentations in 2008. 


\section{NUMIC ECOLOGICAL KNOWLEDGE}

This ongoing project, initiated in 2008, illustrates the use of qualitative and collaborative methods. Compared to the Sherpa example, it represents an attempt to increase the level of collaboration with a host community. An opportunity as a consultant was extended to me while I was in Nepal returning the aforementioned research to the Sherpa and other collaborators. I was asked to assist in creating a relationship between a U.S. national forest and seven Nuwuvi (Southern Paiute) nations who have an ancestral connection to this landscape as their creation place, sponsored by the Southern Nevada Public Lands Management Act (SNPLMA; Fig. 4).

Fig. 4. Newe (Western Shoshone) and Nuwuvi (Southern Paiute) ancestral territory and participating protected areas. All ancestral territory boundaries are approximate. Current reservations and communities represent a fraction of the ancestral territory (see Spoon and Arnold 2012). Participating protected areas include the Spring Mountains National Recreation Area (SMNRA) and the Desert National Wildlife Refuge Complex (DNWRC). Adapted from Kelly and Fowler 1986, Thomas et al. 1986.

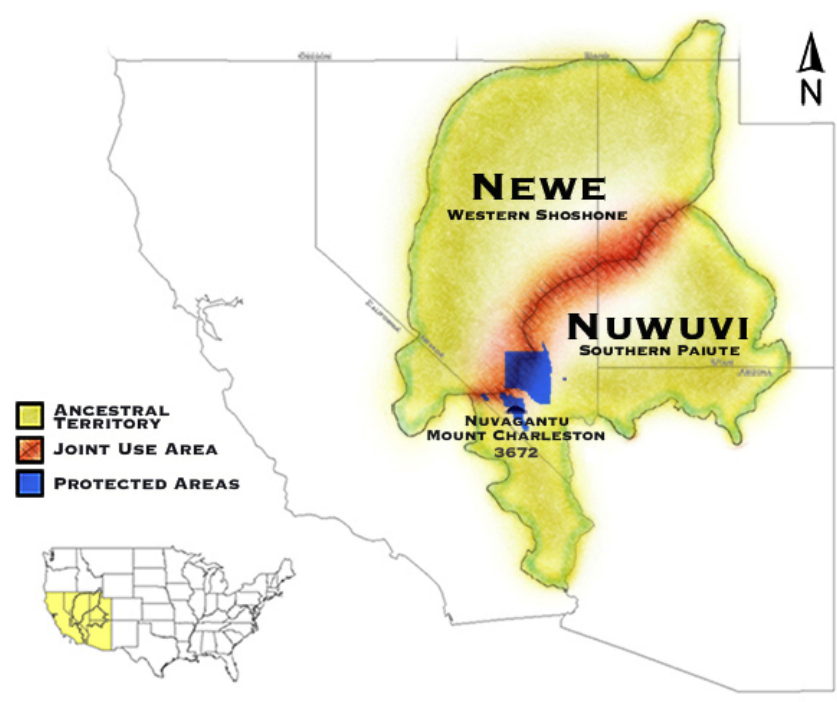

By and large, Nuwuvi and other Numic speaking peoples, such as Newe (Western Shoshone), consider the physical landscape of their ancestral homeland to be their relative, alive and personified. Their oral histories explain that they have inhabited the area since the beginning of time when the world was new, and that they were charged by the Creator to help the land and everything in it to attain a state of balance. This is an adaptive approach in which human interaction is considered mandatory for environmental health.

Starting in the early to mid-nineteenth century, the Nuwuvi population was dramatically reduced (Kelly and Fowler 1986) and their languages were threatened. For example, Nuwuvi currently have less than approximately 50 speakers of their language. Federal agencies and private interests encroached upon their ancestral territory and Numic peoples were relocated to reservations and out-migrated to nearby cities within their ancestral homelands. Current economic strategies are mostly tribal-owned enterprises, such as casinos, tobacco shops, gas stations, and a golf course (Spoon and Arnold 2012).

I traveled to Nevada and by stumbling through cold calls to tribal representatives, networked my way to Richard Arnold, a Pahrump Paiute with extensive experience working with federal agencies and a current chairperson of a federally unrecognized tribe. Richard and I proceeded to collaborate on how to integrate Nuwuvi ecological knowledge into proposed interpretive developments, which included four multimillion dollar visitors centers, as well as other natural and cultural resource management projects. We gathered together tribally designated individuals from each nation into the Nuwuvi Working Group, and together through a series of planning meetings, created the parameters for the research, i.e., what to share and what not to share, for the research questions, and for the proposed consultants.

The group spoke about the importance of intertribal collaboration over time, which occurred both before and after contact with Euro-Americans. They also explained that cultural knowledge, and especially ecological knowledge, was highly heterogeneous and concentrated within the elder generation. Exploratory interviews and focus groups, conducted at the onset of the project, centered on the relationships between Nuwuvi and their creation place, Nuvagantu or 'where snow sits,' reinforced the assertion that knowledge was heterogeneous and specialized. Nuwuvi expressed a need to transmit cultural and ecological knowledge from older to younger generations before the elders passed on or the information diminished. The elders lamented that younger generations did not care about this information. The elders also felt that the younger generations were faced with many distractions that they themselves had not had at younger ages. Tribes who had negative experiences with anthropologists in the past were reluctant to participate is some projects. Because they were the gate-keepers of the knowledge and chose which research consultants they wanted to work with, I decided that the best way to gain their trust and to give them ownership over the research and applied outcomes was to incorporate the host community deeper into the research process.

Consequently, we chose to utilize an accessible qualitative methodology of semistructured interviews, in small focus groups, to collect information on their knowledge of flora, fauna, and other landscape features. Research included knowledge of specific taxa and landscape features, i.e., mountains, rocks, springs, petroglyphs, etc., interrelations among taxa, origin stories, and songs connected to particular locations. This information would consequently serve as content for interpretive exhibits and as resources for managers and tribes. As facilitator, my goal was to stitch together a narrative and to help restore what was perceived as vanishing.

Contrasting with the Sherpa project, this research did not 'test' who knew what and why, but rather inductively assembled a body of knowledge, which was by and large considered under threat or lost. Further, there was sentiment that the restoration of this knowledge and its associated practice would help to rebalance the land, which was suffering from loneliness, neglect, and isolation.

I conducted the first phase of research in 2008-2009 in focus groups with seven Nuwuvi nations. Some working group members coconducted the interviews with me, and we encouraged 
consultants to bring their children to interviews for knowledge transmission opportunities. In later phases, our research took the form of interpretive planning and resource management projects with additional federal agencies and ethnic groups, e.g., U.S. Fish and Wildlife Service and Newe. We shifted from coconducted focus groups to Indigenous researchers and consultants. We enacted 4 research phases in 2011-2013 with 37 individuals (Fig. 5 and 6). Research questions were created collaboratively and working group representatives carried out all of the interviews. Richard and I conducted the analysis and writing; we attempted one collaborative analysis, which ended up being very difficult to complete. The working group and the participants reviewed the interview transcripts and final reports for accuracy and content. The reports now serve as the basis for interpretive exhibits in four visitor centers, surrounding landscapes and some management activities (Spoon et al. 2011, 2012a, b, Spoon and Arnold 2012).

Fig. 5. Interviews and focus groups conducted by Nuwuvi (Southern Paiute) Working Group members with Nuwuvi knowledge holders at the Pahranagat National Wildlife Refuge (part of the Desert National Wildlife Refuge Complex), Nevada. June 2013. Photo: Jeremy Spoon.

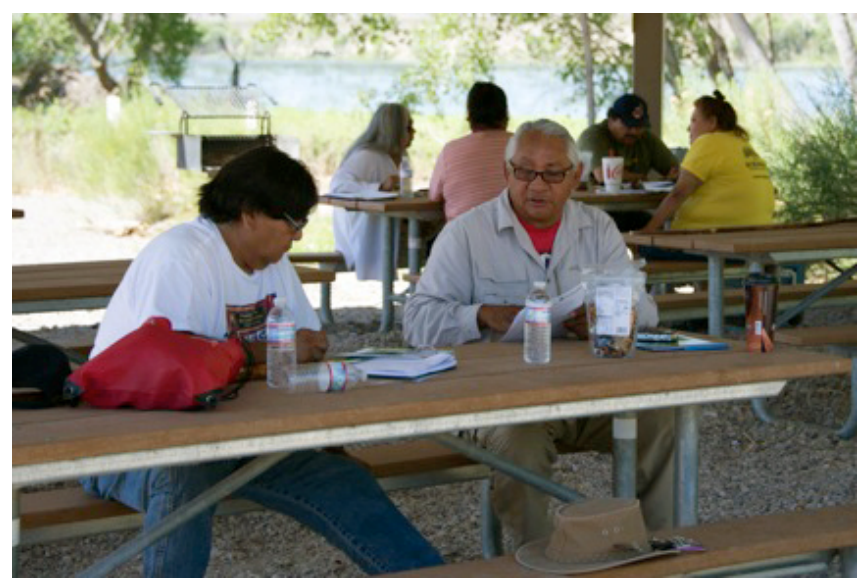

Results generally showed that ecological knowledge was indeed highly fragmented and that the political and economic context drastically affected how Numic peoples see and interact with place. Much of this information was concentrated in elder cohorts and specialists, and many of the younger generations and the general population had not been exposed to it. The findings also showed the hybridization of ecological knowledge and understanding and how it had been influenced by severance from ancestral lands, reservation relocation, forced attendance at government boarding schools, varying participation in different denominations of Christianity, the development of Las Vegas, and general disenfranchisement from the state. For example, it was more common for consultants to know the common names for taxa, springs, and place names in English rather than in the Numic languages. Some felt that we were still in the contact period, a departure from a more idealized time before contact when things were thought to be better; a time that is generally considered healthier for both people and place. (Spoon and Arnold 2012, Spoon et al. 2011, 2012a,b).
Fig. 6. Newe (Western Shoshone), Nuwuvi (Southern Paiute), U.S. Fish and Wildlife Service, and Portland State University/ The Mountain Institute participants in collaborative research at Ash Meadows National Wildlife Refuge (part of the Desert National Wildlife Refuge Complex), Nevada. April 2012. Photo: Jeremy Spoon.

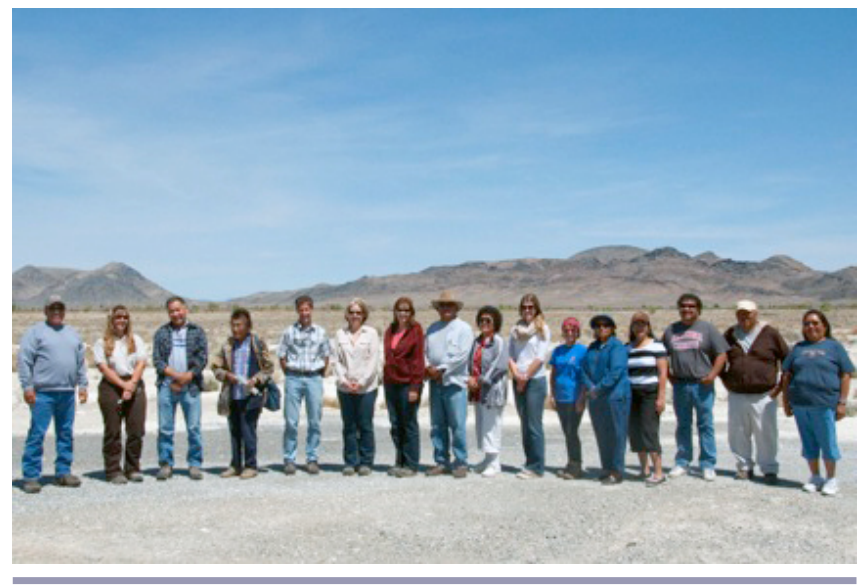

These projects were inherently applied as they were tied to federal contracts with predetermined deliverables, e.g., reports with content for visitors center exhibits and films, a consultation handbook, a resource stewardship plan, and a public-use site plan. We strived to create outcomes that benefited all involved, i.e., Native Americans, federal agency representatives, and the public. We worked with both the tribes and the federal agencies to make this happen. The highly contested relationship between tribes and federal agencies continues to be quite fragile and is personality based; however, the approach proved that rapport building between once adversarial entities assists in the communication of mutually conceived outcomes. Further, capacity was built among Native American researchers so that they can continue to be invested in collecting ethnographic information.

Challenges with this project included misunderstandings related to the transition from the collaborative research to a final deliverable acceptable by the federal agency funders. The collaborative methodology forced me to give up a degree of control in the research process. The research design, methods, and data analysis also had to be accessible to the participants. This repositioning created ownership for the project among the group; however, in the end, I as the principal investigator, was responsible for submitting the reports so that everyone was paid. Some participants felt that they had more ownership over the products and that certain thoughts were not reflected in reports and visitor center designs. The multivocality of the working group and the contractual obligation to funders made agreeing on final products contested and challenging, although not insurmountable through dialogue, compromise, and transparency. The traditional grant format, compared to contracts, may have made enacting this collaborative methodology easier because it did not require the deliverables to be approved by the funder before the distribution of funds; however, in this case, the contract model led directly to applied outcomes, which are often left out of the grant paradigm. 
Numic consultants did also articulate some strategic essentialism (Li 2000, Robins 2001) at times to justify their connection to landscapes currently under federal governance, especially a romanticized perspective of the precontact period as static and harmonious. Indeed, indigeneity often becomes an articulated identity for largely political reasons, especially in situations in which the contact zone represents highly unequal power relations between Indigenous and various settler populations (Clifford 2001). This bias translated into consultants censoring certain information that did not seem 'traditional' enough for the federal agency representatives. Other issues included ethnographers straying from the research questions and Native consultants gatekeeping information from other Native consultants.

\section{DISCUSSION}

\section{Linked quantitative and qualitative methods}

The use of linked quantitative and qualitative methods in research on Indigenous ecological knowledge allows data to be layered, demonstrating broader, macro trends and specific nuances at a particular time, which are comparable temporally. Quantitative ethnographic methods often require large sample sizes and have a reliable system for answering specific research questions, which can be generalized across a certain population over time. Data collection can occur quite quickly depending on the accessibility of the sample and questionnaire format, underscoring the importance of sound research design and questions. The enduring strength of quantitative techniques is in illustrating broader trends, ideally repeatable across a wide temporal scale. For example, the use of quantitative methods to assess changes in Maya plant name knowledge over a 30-year period showed that knowledge change was not occurring, potentially because children helped parents in agricultural tasks after school (Zarger and Stepp 2004). The research design and quantitative data allowed results to be comparable over time, which is more difficult with qualitative techniques. These insights can then be applied to other questions regarding local knowledge and the forces of change or lack thereof.

Conversely, quantitative methods can have limited depth because of the nature of a quantified, positivist approach. Variables must be reduced to measurable units, which can simplify or misinterpret the dynamics of cultural phenomena without proper context. Quantitative methods are rigid and can segregate information from broader knowledge frameworks, such as conducting research on names and uses of a specific plant species, while overlooking local frameworks for how certain plant species interact with landscape-level spiritual powers and how these powers are influenced by ecological, political, or economic forces. Qualitative methods thus offer a more flexible format to inductively explore a knowledge domain or practice.

Qualitative ethnographic methods, often from smaller sample sizes, can provide inductive insight into knowledge assemblages and how they change over time. The data can express emergent themes related to how Indigenous peoples construct nature and how this knowledge generates behavior and provides a framework for the interpretation of experience in a particular physical environment. Data from qualitative methods, such as in situ unstructured and semistructured interviews, can thus buttress quantitative data, assisting in the triangulation and interpretation of results. For example, the Sherpa life histories helped to frame how multiple generations of male and female Sherpa, near and far from the tourist route with differing levels of Western education, saw and interacted with the environment. This information provided context to the statistical results that knowledge change was occurring related to species and placebased spiritual concept knowledge, i.e., sacred valleys, mountains, rocks, water sources, forests, and trees, across age, gender, and proximity to the tourist route.

Woodward et al. (2012) conducted linked quantitative and qualitative methods with Indigenous peoples in the Northern Territory of Australia and found that both data collection techniques provided different, complementary information, which could inform water resource management. Quantitative data revealed exact locations for aquatic resources and harvesting techniques, and qualitative data afforded information on the seasonal resource use calendar and associated resource-use patterns. As in the Sherpa research, Morse and Niehaus (2009) recommended using a quantitative or qualitative core component of research and a supplemental component that fits into the core component of the study, e.g., quantitative methods were core in the Sherpa example. Caution should be practiced when generalizing qualitative data from small, nonprobabilistic sample sizes; they may not adequately express heterogeneity across certain facets of a population and prompt a subjective bias.

Quantitative survey data collected in tandem with linked quantitative and qualitative ethnographic information assists in framing research on human-environment relationships, especially in understanding a population's dynamics over time. For example, Vaccaro and Beltran (2007) used demographics and ethnographic data to show that life for Eastern Pyrenees settlers shifted when markets caused farming to be less viable than tourism. Beltran (2010) argued that demography in this case showed that population types and dynamics were intertwined with environmental relationships; rhythm of growth and settlement patterns reflected the reactions of a given population to the opportunities and constraints presented by the environment. $\mathrm{He}$ also argued that demography, when collected precisely and critically, achieves higher accuracy than many other indicators. With a solid research design, trained local collaborators can also conduct demographic surveys, affording more local investment in a research project.

Linked quantitative and qualitative methods also assist in the translation of social science information to predominantly natural science contexts, which can subsequently be applied to policy and management. Quantitative research in environmental anthropology is on the decline, whereas calls for the integration of natural and social science data in the development of environmental policy are on the rise (Charnley and Durham 2010). Quantitative social science data have the potential to be integrated more easily with natural science information, especially useful in research on coupled social-ecological systems. Further, adding a qualitative component creates a thicker description and assists in the interpretation of the quantitative information so that it does not stand alone in a vacuum.

Select studies have documented the difficulty in synching data sets of local/Indigenous/traditional ecological knowledge and Western scientific knowledge (Huntington 2000, Huntington et 
al. 2004, Moller et al. 2009). Moller et al (2004) argued that traditional ecological knowledge and Western science are most compatible in natural resource management, such as the integration of Sherpa spiritual taboos on the killing of animals, harvesting of select forest products, and pollution of water sources into protected area management (Spoon 2011a). Raymond et al. (2010) added that there is no single superior method for the integration of knowledge types, rather a focus on the process of knowledge integration is more effective, such as the use of collaborative methods.

\section{Collaborative methods}

Collaborative ethnographic and survey methods offer opportunities to develop rapport, locally important research questions, unique methodological tool-kits, and insights into the interpretation of results. Many Indigenous populations have a unique connection with a particular environmental context. First peoples may not govern these environments, especially in the case of protected areas. Further, as in the case of Native Americans, Indigenous peoples may be marginalized by colonial, postcolonial, and neocolonial processes, which have led to numerous health issues from depression to obesity and diabetes (O'Brien 2008). In the Numic case, collaborative methods offered opportunities to reunite Indigenous peoples with ancestral landscapes and to build capacity. They also created the potential to integrate different ways of knowing into environmental management, e.g., pine nut harvests in pinion-juniper habitats as a form of management, and in certain cases, public education, for example, visitor center exhibits and public art.

Strang (2006) argued that contemporary ethnographic research has generally evolved into a process of collaboration with host populations. She stated that it has increasingly become the norm for Indigenous populations and others to initiate, fund and oversee ethnographic research, assist in the design and development of research projects, or at minimum, set expectations for ethical project processes and outcomes. These collaborations thus create hybrid outcomes between researcher and host population. Lassiter (2005) characterized collaborative ethnography as both a theoretical and methodological technique that emphasizes collaboration throughout the ethnographic process. This includes project conceptualization, fieldwork, and writing. Products are thus coconceived or cowritten with collaborators and consider multiple audiences.

Collaborative methods engage ethical questions regarding the objectives of proposed research projects and the outcomes that result. These methods were found to create more local involvement and ownership of cultural landscape research (Strang 2006, 2010), provide opportunities for the writing of alternative histories (Frank et al. 2008, Archambault 2011), serve as a contextual framing for research on human-environment dynamics over time (Kalibo and Medley 2007, ColwellChanthaphonh and Ferguson 2010, Strang 2010), and offer opportunities for disparate knowledge holders to colearn, such as Indigenous peoples and protected area managers (Spoon 2011a, Spoon and Arnold 2012).

Further, collaborative methods provide opportunities to overcome internally and externally imposed boundaries that affect who participates in research projects and what they share, especially in Western countries where Indigenous peoples live alongside nonnative settler populations. For example, a research project with an Indigenous people who have negative experiences with settler groups, such as Native Americans, Canadian First Nations, and Aboriginal Australians, may be stunted by the previous experiences of the host population. For justified reasons, they may see no benefit in the effort and may gate-keep access to participants.

Based on the aforementioned experiences, I recommend instituting a capacity building component or feedback mechanism in which Indigenous researchers are trained (if necessary) to conduct ethnographic and survey methods, as well as returning final products to Indigenous institutions. It is also suggested that these individuals are either compensated for their efforts and time away from their jobs or contribute to a mutually conceived outcome(s). This framework can indeed generate high quality research with collaborators who typically may not take part in projects or may withhold information. Training is vital, as is extensive dialogue on the research questions and methods. I recommend quantitative structured demographic surveys and qualitative focus groups of three to four participants.

Admittedly, collaborative research can be quite nebulous and can shift by project and context. Collaborative techniques can create misunderstandings in project objectives, especially in cases in which external funding is driving a project and the deliverables must be approved by a funder, such as a government agency or aid organization. It is important to manage expectations from the start. Some projects have collaborative components at the onset, whereas others utilize this framework in the implementation of research methods, and more rarely, collaborate on analysis and the writing of research products, such as the review of individual chapters by focus groups, which encompass editorial boards appointed by the community (Lobo et al. 2002, Lassiter 2005, Field 2008). In the Numic case, collaboration entailed relinquishing a level of control to the Indigenous communities, which became challenging when contract obligations necessitated the researcher to submit final products acceptable to the funder for project payment. This repositioning also created challenges in the transformation of research products into academic publications.

There are issues with collaborative methods, especially with guarded and contested information. Host communities may be willing to share information internally with their own ethnographers; however they may be unwilling to share this information with external actors, i.e., federal agencies or the public. If these actors funded the research and expected certain outcomes, the ethnography may be guarded. The research design and methods must be feasible and accessible to the host population. For the Numic project, this ruled out large probabilistic sample sizes and complex multimethod approaches, especially quantitative techniques. Further, when information collected through collaborative processes is exposed to the public, for example as online reports, in museum exhibits, or films, high levels of contestation may result. Indigenous peoples are far from homogenous populations and thus the multitude of perspectives may make it difficult to agree upon an outcome, let alone reach consensus. It is vital at the onset of a project to be as transparent as possible to ensure that there are no misunderstandings down the line. The focus is thus on process and less on product. 


\section{CONCLUSION}

I present suites of quantitative, qualitative, and collaborative methods, which address Indigenous ecological knowledge assemblages depending on context and actors. In the Sherpa case, linked quantitative, qualitative, and collaborative methods yielded information on macro trends occurring within the population and the character of the knowledge/practice assemblages at that time. The project engaged locally relevant research questions and afforded opportunities for the capacity building of research assistants. The Numic case relied solely on qualitative methods based on assumptions generated through pilot research conducted in collaboration with a working group of tribally designated individuals. Collaborative methods were used throughout; a level of control was given to the group. Rapport was built between the Indigenous peoples and the federal agencies, which translated into increased consultation beyond federally mandated policy and expectations. In both cases, I utilized suites of methods informed by context, providing insights that fed back into future methodological approaches. Research on Indigenous ecological knowledge will always have flaws because of the dynamic, adaptive, and hybridized nature of knowledge and practices. However, through appropriate reconnaissance, rapport, and the selection of context-specific suites of methods, research can better progress understanding about the relationships between humans and the environment.

\section{Responses to this article can be read online at:}

http://www.ecologyandsociety.org/issues/responses. $\mathrm{php} / 6549$

\section{Acknowledgments:}

A Graduate Research Fellowship awarded from the National Science Foundation (NSF) and various contracts awarded from the Southern Nevada Public Lands Management Act (SNPLMA) funded this research. It would not have been possible without the help of the Khumbu Sherpa community and Nuwuvi and Newe Nations. Thanks to Dr. Lhakpa Norbu Sherpa, Pemba Tshering Sherpa, Ngima Nuru Sherpa, The Mountain Institute, Khumbu Bijuli Company and the Department of National Parks and Wildlife Conservation, Nepal. Thanks also to Richard Arnold, Judy Suing, Kevin DesRoberts, the Nuwuvi/Newe Working Group, and the U.S. Forest and Fish and Wildlife Services. Christopher Milton and Sarah Jovan were also instrumental in map making and providing comments. I am solely responsible for any errors.

\section{LITERATURE CITED}

Archambault, J. 2011. Native communities, museums and collaboration. Practicing Anthropology 33(2):16-20.

Asch, M., C. Samson, D. Heinen, J. Kenrick, J. Lewis, S. Saugestad, and T. Turner. 2004. On the return of the native. Current Anthropology 45: 261-265. http://dx.doi.org/10.1086/382253

Beltran, O. 2010. People, numbers, and natural resources: demography in environmental research. Pages 11-34 in I. Vaccaro, E. A. Smith, and S. Aswani, editors. Environmental social sciences: methods and research design. Cambridge University Press, Cambridge, UK.
Berkes, F. 2008. Sacred ecology: traditional ecological knowledge and resource management. Routledge, New York, New York, USA.

Berkes, F., and N. L. Turner. 2006. Knowledge, learning, and the evolution of conservation practice for social-ecological system resilience. Human Ecology 34(4):479-494. http://dx.doi. org/10.1007/s10745-006-9008-2

Charnley, S., and W. H. Durham. 2010. Anthropology and environmental policy: what counts? American Anthropologist 112 (3):397-415. http://dx.doi.org/10.1111/j.1548-1433.2010.01248.x

Clifford, J. 2001. Indigenous articulations. Contemporary Pacific 13(2):467-490. http://dx.doi.org/10.1353/cp.2001.0046

Colwell-Chanthaphonh, C., and T. J. Ferguson. 2010. Intersecting magisteria: bridging archaeological science and traditional knowledge. Journal of Social Archaeology 10(3):325. http://dx. doi.org/10.1177/1469605310377960

Dove, M., D. S. Smith, M. T. Campos, A. S. Mathews, A. Rademacher, S. Rhee, and L. M. Yoder. 2009. Globalisation and the construction of western and non-western knowledge. Pages 129-154 in P. Sillitoe, editor. Local science vs. global science: approaches to indigenous knowledge in international development. Berghahn Books, Oxford, UK.

Field, L. W. 2008. "Side by side or facing one another": writing and collaborative ethnography in comparative perspective. Collaborative Anthropologies 1:32-50. http://dx.doi.org/10.1353/ cla. 0.0011

Frank, G., S. Murphy, H. J. Kitching, D. M. Garfield, Sr., and N. McDarment. 2008. The Tule River tribal history project: evaluating a California tribal government's collaboration with anthropology and occupational therapy to preserve indigenous history and promote tribal goals. Human Organization 67 (4):430-442.

Huntington, H. P. 2000. Using traditional ecological knowledge in science: methods and applications. Ecological Applications 10 (5):1270-1274. http://dx.doi.org/10.1890/1051-0761(2000)010[1270: UTEKIS]2.0.CO;2

Huntington, H., T. Callaghan, S. Fox, and I. Krupnik. 2004. Matching traditional and scientific observations to detect environmental change: a discussion on Arctic terrestrial ecosystems. Ambio 13:18-23.

Kalibo, H. W., and K. E. Medley. 2007. Participatory resource mapping for adaptive collaborative management at Mt. Kasigau, Kenya. Landscape and Urban Planning 82(3):145-158. http://dx. doi.org/10.1016/j.landurbplan.2007.02.005

Kelly, I. T., and C. S. Fowler. 1986. Southern Paiute. Pages 368-397 in W. L. D'Azevedo, editor. Handbook of North Americans Indians: Great Basin. Smithsonian Institution, Washington, D.C., USA.

Lassiter, L. E. 2005. The Chicago guide to collaborative ethnography. University of Chicago Press, Chicago, USA. http:// dx.doi.org/10.7208/chicago/9780226467016.001.0001

Lauer, M. 2012. Oral traditions or situated practices? Understanding how indigenous communities respond to environmental disasters. Human Organization 71(2):176-187. 
Li, T. M. 2000. Articulating indigenous identity in Indonesia: resource politics and the tribal slot. Comparative Studies in Society and History 42:149-179. http://dx.doi.org/10.1017/S0010417500002632

Lobo, S., S. M. Bennett, C. Betsillie, J. Keoke, G. M. Lira, and M. L. St. Germaine, editors. 2002. Urban voices: the Bay Area American Indian community. University of Arizona Press, Tucson, Arizona, USA.

Moller, H., F. Berkes, P. O. B. Lyver, and M. Kislalioglu. 2004. Combining science and traditional ecological knowledge: monitoring populations for co-management. Ecology and Society 9(3): 2. [online] URL: http://www.ecologyandsociety.org/vol9/ iss3/art2/inline.html

Moller, H., P. O’Blyver, C. Bragg, J. Newman, R. Clucas, D. Fletcher, J. Kitson, S. McKechnie, and D. Scott. 2009. Guidelines for cross-cultural participatory action research partnerships: a case study of a customary seabird harvest in New Zealand. Journal of Zoology 36(3):211-241. [online] URL: https://www. maths.otago.ac.nz/home/resources/david_fletcher/Moller_et_al_2009a. pdf

Morse, J. M., and L. Niehaus. 2009. Mixed method design: principles and procedures. Left Coast, Walnut Creek, California, USA.

O'Brien, S. J. C., editor. 2008. Religion and healing in Native America: pathways for renewal. Praeger, Westport, Connecticut, USA.

Ortner, S. B. 1989. High religion: a cultural and political history of Sherpa Buddhism. Princeton University Press, Princeton, New Jersey, USA.

Raymond, C. M., I. Fazey, M. S. Reed, L. C. Stringer, G. M. Robinson, and A. C. Evely. 2010. Integrating local and scientific knowledge for environmental management. Journal of Environmental Management 91(8):1766-1777. http://dx.doi. org/10.1016/j.jenvman.2010.03.023

Robins, S. 2001. NGOs, 'Bushmen,' and double vision: the $p$ khomani San land claim and the cultural politics of 'community' and 'development' in the Kalahari. Journal of Southern African Studies 27:833-853. http://dx.doi.org/10.1080/03057070120090763

Sillitoe, P. 1998. The development of indigenous knowledge: a new applied anthropology. Current Anthropology 39(2):223-252. http://dx.doi.org/10.1086/204722

Spoon, J. 2011a. The heterogeneity of Khumbu Sherpa ecological knowledge and understanding in Sagarmatha (Mount Everest) National Park and Buffer Zone, Nepal. Human Ecology 39 (5):657-672. http://dx.doi.org/10.1007/s10745-011-9424-9

Spoon, J. 2011b. Tourism, persistence, and change: Sherpa spirituality and place in Sagarmatha (Mount Everest) National Park and Buffer Zone, Nepal. Journal of Ecological Anthropology 15(1):41-57. [online] URL: http://pdxscholar.library.pdx.edu/ anth fac/1/

Spoon, J. 2013. From yaks to tourists: Sherpa livelihood adaptations in Sagarmatha (Mount Everest National Park and Buffer Zone, Nepal. Pages 319-340 in L. R. Lozny, editor. Continuity and change in cultural mountain adaptation: from prehistory to contemporary threats. Springer, New York, New York, USA.

Spoon, J., and R. Arnold. 2012. Collaborative research and colearning: integrating Nuwuvi (Southern Paiute) ecological knowledge and spirituality to revitalize a fragmented land. Journal for the Study of Religion, Nature, and Culture 6.4 (2013):477-500.

Spoon, J., R. Arnold, and the Nuwuvi Working Group. $2012 a$. Our gathering place: Newe (Western Shoshone), Nuwuvi (Southern Paiute), and the Ash Meadows landscape. Mountain Institute and Portland State University, Portland, Oregon, USA.

Spoon, J., R. Arnold, and the Nuwuvi Working Group. $2012 b$. Nuwu-Vots (our footprints): Nuwuvi (Southern Paiute) and the Pahranagat Valley. Mountain Institute and Portland State University, Portland, Oregon, USA.

Spoon, J., R. Arnold, and the Nuwuvi Working Group. 2011. Nuwu Kanee, Nuwu Tooveenup (our home, our story): Nuwuvi (Southern Paiute) and the Spring Mountains. Mountain Institute and Portland State University, Portland, Oregon, USA.

Strang, V. 2010. Mapping histories: cultural landscapes and walkabout methods. Pages 132-156 in I. Vaccaro, E. Smith, and S. Aswani, editors. Environmental social sciences: methods and research design. Cambridge University Press, Cambridge, UK.

Strang, V. 2006. A happy coincidence? Symbiosis and synthesis in anthropological and indigenous knowledges. Current Anthropology 47(6):981-1008. http://dx.doi.org/10.1086/507196

Thomas, D. W., L. S. A. Pendleton, and S. C. Cappannnari. 1986. Western Shoshone. Pages 262-283 in W. L. D'Azevedo, editor. Handbook of North Americans Indians: Great Basin. Smithsonian Institution, Washington, D.C., USA.

Turner, N. J., and F. Berkes. 2006. Coming to understanding: developing conservation through incremental learning in the Pacific Northwest. Human Ecology 34:495-513. http://dx.doi. org/10.1007/s10745-006-9042-0

Vaccaro, I., and O. Beltran. 2007. Consuming space, nature and culture: patrimonial discussions in the hyper-modern era. Tourism Geographies 9:254-274. http://dx.doi.org/10.1080/14616680701422715

Woodward, E., S. Jackson, M. Finn, and P. M. McTaggart. 2012. Utilising indigenous seasonal knowledge to understand aquatic resource use and inform water resource management in northern Australia. Ecological Management and Restoration 13(1):58-64. http://dx.doi.org/10.1111/j.1442-8903.2011.00622.x

Zarger, R. K., and J. R. Stepp. 2004. Persistence of botanical knowledge among Tzeltal Maya children. Current Anthropology 45(3):413-418. http://dx.doi.org/10.1086/420908 